\title{
VITICULURE LABOUR RECRUITMENT AND RETENTION ISSUES
}

\author{
Wei Wei Mao, Graduate Diploma in HR \\ Michelle Shields, Senior Lecturer
}

\author{
School of Business \\ Christchurch College of Education
}

\begin{abstract}
Those involved in the New Zealand wine industry have voiced concerns about increasing labour shortages, wage issues, and working conditions for short-term labourers in the viticulture industry. This research is aimed at clarifying issues related to recruitment and retention of workers in New Zealand vineyards. The research is exploratory in nature and includes a review of recent literature on the extent and nature of the problem and provides survey feedback from individual workers and members of viticulture management on the factors that affect labour recruitment and retention. Key findings from the survey are that wages and, by extension, the cost of accommodation, are critical factors affecting workers' decisions to return to the industry in subsequent seasons. In addition, viticulture owners and managers report that selection of contractor-supervisors is pivotal in ensuring appropriate worker skills are available during peak production periods.
\end{abstract}

\section{Introduction}

The wine industry plays an essential role in the agricultural economy of New Zealand. As a major industry, it provides a large number of jobs during the harvest and pruning seasons. However, the selection and retention of contractors in the viticulture industry has become a growing issue in recent years due in part to rapid growth in the industry (e.g. New Zealand Wine Online 2004) and in part to the tight labour market that exists at present (Boxall, Macky and Rasmussen 2003).

This research looks at:

The extent of the problem of recruiting viticulture workers.

The issue of retaining workers from season to season.

The motivation factors that encourage workers to continue working with a particular vineyard.

Strategies that can be put in place for recruiting and retaining vineyard workers.

To help understand these questions, the research takes an exploratory approach utilising a review of recent press and journal articles and combines these with questionnaire results gathered from forty seasonal labourers working in the viticulture industry and four vineyard owners/managers.

\section{Literature Review}

A literature review was undertaken on the topic of contractor selection and retention in New Zealand vineyards. As this issue has only recently come to public attention, most articles related to this issue have appeared in the press in the last few years. This literature review looks at the extent of the labour shortage in viticulture and issues surrounding selection and retention of viticulture workers.

\section{Growth in the Viticulture Industry}

The New Zealand grape growing (viticulture) industry is growing at a phenomenal rate. It is estimated that 1200 extra hectares of grapes are being planted in Marlborough each year (Porter 2001). As shown in Table 1 the wine industry of New Zealand has developed rapidly in recent years with increasing area devoted to grape growing and increasing memberships in the NZ wine institute (New Zealand Wine Online 2004). While New Zealand celebrates this development, this growth means that more and more workers are needed. According to The Dominion ("Shortage of labour" 2002), the shortage of workers is disastrous for the industry and will only get worse as more land is put into grapes. As shown in Table 1 , the total hectares have grown by over $75 \%$ in five years. Montana, one of the largest operations, is expanding its vineyards by 200 ha annually and places staffing as its major future concern (Porter 2001). While it may be relatively cost-effective to have labour turnover running at around $15 \%$ per annum in low-wage sectors (Boxall, Macky and Rasmussen 2003), the current era of tight labour markets suggests that employee turnover even in low wage jobs is problematic for employers.

It is impossible for anyone working in a vineyard fulltime to do so without any skills or knowledge in the field. Queensland Government (Banks, Oag and Dullahide 2004) has alerted grape growers to be aware that setting up a vineyard involves land preparation, erecting trellises, installing an irrigation system and planting vines. In mature vines, there is winter pruning, chemical spraying for most of the growing season as well as normal fertilizing and watering requirements. All of these activities require some skills. Hence, vineyard managers seeking help with these tasks need to select their staff carefully. 
Adding to the problem is the seasonal aspect of the work as labour is needed intensively for a short period of time. For best grapes and hence wine quality, fruit must be harvested as quickly as possible once it has reached the maturity the winemaker desires (Banks et al. 2004). That means harvesting grapes must be conducted within three to four days.

\section{Extent of the Labour Shortage}

Because of the rapid growth rate in the industry, precise statistics on the number of workers needed to meet the labour demand become outdated quickly. In Marlborough alone however, it has been forecast that at current growth rates 300-400 new workers will be needed every year over the next six years (Easton 2004). According to Easton, last year, the Marlborough region had over 8000 hectares of grapes to prune and approximately 1250 workers were needed to complete the task. While not representative of the entire industry in New Zcaland, the Marlborough region has about $45 \%$ of the country's vineyards suggesting says Easton, that issues facing this region will eventually spread to other wine regions in New Zealand as the industry grows.

Devereux (2004) discusses the excellent growing conditions as one factor contributing to 2004 being one of the best crop harvests in several years. He predicted that the national crop was likely to total 21 million cartons, and that up to 40,000 pickers were needed across the country. Overall, wine production increased by $35 \%$ in 2004 ("Benefits of Bumper" 2004) placing further pressure on labour needed to process grapes.

\section{Factors Affecting Worker Recruitment and Retention}

Low pay is a significant factor contributing to the labour shortage. According to Hutchinson and Wilson (2004) Marlborough will continue to face a chronic labour shortage until issues of low wages are addressed. Adding to this, they note that Marlborough had the lowest unemployment rate in New Zealand. One criticism levelled against the industry by the Central Amalgamated Workers Union is that the industry is caught in a "time warp" when it comes to wages and that people are expected to live on "sunshine rates" because a grape growing region is a nice place to live (Moriarty 2003). According to Moriarty, wages in Marlborough in 2003 were at \$10-\$12 an hour and vineyard owners were paying between $\$ 14-\$ 16$ per hour to the contractor employing the worker.

While one contractor in the federation of contractors said that low pay meant there would never be enough workers, others have said that the real problem is accommodation ("Grape contractors" 2004). In one instance it was reported that people were camping in tents under bridges and on private farmland because of the high cost and lack of short-term accommodation (Moriarty 2003). This is, says Moriarty, a particularly problematic issue for workers coming from out of town to work during peak seasons.

Table 1: Wine Industry Growth and Development

\begin{tabular}{|c|c|c|c|c|c|c|}
\hline Year & 1999 & 2000 & 2001 & 2002 & 2003 & 2004 \\
\hline Total Ha & 9,000 & 10,197 & 11,275 & 12,822 & 14,802 & 15,829 \\
\hline \multicolumn{7}{|c|}{ Wine Institute Membership 1999-2004 } \\
\hline Year & 1999 & 2000 & 2001 & 2002 & 2003 & 2004 \\
\hline Total Mbsh & 334 & 358 & 397 & 398 & 454 & 460 \\
\hline
\end{tabular}

Source: New Zealand Wine Institute

A third issue of concern to those in the industry is the relative skill level of workers ("Labour Crews Act" 2001). It used to be that employers in the viticulture industry were comfortable employing unskilled workers to pick their grapes but now prefer to have the same workforce consistently and want to train them (Wilson 2003, Feb 5). According to Minister Steve Maharey (cited in Wilson) retention of workers is only possible if vineyards are prepared to pay for them. Lastly, many of the workers employers are trying to retain may be those who are least interested in staying or returning -- students and tourists. Students and summer backpackers often leave the growing areas when they are needed the most during harvest season (Porter 2001). Tony Smale, Marlborough Economic Trust chairman (as cited in Porter) asserts that these young people leave the grape growing regions lured by the attractiveness of urban areas and don't return to the agricultural regions until they are 45 to 50 years old

Overall, wages, accommodation costs and skill levels are all factors believed to affect recruitment and retention of workers in the viticulture industry. To test these assumptions, a survey of workers and vineyard owners/managers was undertaken. 


\section{Methodology and Sample Description}

This research focuses on the New Zealand wine industry by gathering information regarding worker recruitment and retention as reported by contractors and New Zealand vineyard owners or managers.

Mail and phone questionnaires were used to gather data from the 40 non-regular vineyard workers, or individual contractors. Respondents were asked about:

- Whether they were currently working in the viticulture industry and for how long.

- What factors affected their decision to return to the industry and to a particular vineyard to work.

- What factors affected their decision to leave the industry.

- Whether they were hired independently or through an agent/contractor supervisor.

- How important factors such as wages, accommodation, and transportation were to them.

- Their perceptions of what vineyard owners are looking for in contractors.

- Whether they would continue to communicate with the vineyard owner or contractor-supervisor once their seasonal work was completed.

Data was also collected using face-to-face interviews and open-ended email questionnaires with two vineyard owners and two vineyard managers from the Canterbury and Marlborough regions respectively.

Respondents were asked about:

- The location and the size of the vineyards.

- Their current situation regarding employment.

- Their reasons for using contractors.

- The methods of selecting contractors.

- The requirements for selecting contractors.

- Whether they provide training for new contractors.

- Their opinions regarding contractor turnover.

- Whether they offer any incentives for contractors to stay.
- Whether they contact contractors post-season.

- Their suggestion regarding contractor selection and retention.

\section{Results}

The following section presents the findings from the survey and interviews.

\section{Results: Survey of Individual Contractors}

The first question asked whether contractors were currently working in vineyards. Of the 40 respondents, 23 $(57 \%)$ reported that they had stopped working in vineyards. 17 of respondents $(43 \%)$ reported that they were currently working in vineyards. 36 respondents $(90 \%)$ said they worked or had worked less than one year, and four respondents $(10 \%)$ said they had worked in the industry for more than a year. The reasons given by these four respondents for staying in the industry were job familiarisation, adequate pay, satisfactory working conditions, gaining more working experience and established friendship with vineyard owners.

Respondents were then asked why they had or might leave the industry. The reasons given are shown in Table 2. $35 \%$ of respondents $(n=14)$ have stopped or may stop working in vineyards due to insufficient financial rewards. The second reason was accommodation costs. This accounts for $33 \%$ of individual contractor respondents $(n=13)$. Poor working condition and returning to school were two other main reasons that affected the decision to stop working in vineyards. These reasons account for $28 \%$ and $25 \%$ respectively. $13 \%$ of respondents $(n=5)$ said transport was a barrier for ongoing work in vineyards. In addition, $10 \%$ of respondents $(n=4)$ reported that hard physical work made or might make them stop working. The other reasons given were poor accommodation quality $(8 \%, n=3)$, family problems $(5 \%$, $\mathrm{n}=2$ ), working only for short time in order to gain working experience $(3 \%, n=1)$, found another job $(3 \%$, $n=1)$, excessively long working hours $(3 \%, n=1)$, insufficient work $(3 \%, n=1)$ and visa problem $(3 \%, n=1)$.

When asked whether they would like to go back to or continue to work in viticulture if they had an opportunity to do so, $50 \%$ of individual contractor respondents $(n=20)$ said "yes", and another $50 \%$ of individual contractor respondents $(n=20)$ said "no", they would not go back to work in the viticulture industry. 
Table 2: Reasons for leaving the Vineyard Industry

\begin{tabular}{|l|c|c|}
\hline Reasons & Numbers of response & Percentage \\
\hline Insufficient financial rewards & 14 & $35 \%$ \\
\hline Accommodation costs & 13 & $33 \%$ \\
\hline Poor working conditions & 11 & $28 \%$ \\
\hline Back to school & 10 & $25 \%$ \\
\hline Transportation problems & 5 & $13 \%$ \\
\hline Hard physical work & 4 & $10 \%$ \\
\hline Poor accommodation quality & 3 & $8 \%$ \\
\hline Family problems & 2 & $5 \%$ \\
\hline Work experience programme & 1 & $3 \%$ \\
\hline Found another job & 1 & $3 \%$ \\
\hline Long working hours & 1 & $3 \%$ \\
\hline Insufficient work & 1 & $3 \%$ \\
\hline Visa problem & 1 & $3 \%$ \\
\hline
\end{tabular}

Earning money was an important factor for respondents choosing to return to work in vineyards. This accounts for $65 \%(n=13)$ compared with other factors among the 20 respondents. Second was gaining working experience $(35 \%, n=7) .20 \%(n=4)$ of respondents said the natural work environment attracts them to remain working in vineyards. Other reasons given for returning to the industry were: easy to do or no special skills required $(10 \%, n=2)$, interested in the work $(5 \%, n=1)$, love to meet people in this type of work $(5 \%, \mathrm{n}=1)$, and spending school holidays $(5 \%, n=1)$.

Of the $50 \%$ who would not return even if given opportunity to do so said that poor working conditions and finding another job were the main reasons given. This accounts for $30 \%(n=6)$ of the 20 respondents who reported they had already left the industry. $25 \%$ of respondents $(n=5)$ said they had lost interest in the work. $20 \%$ of respondents $(n=4)$ thought it was hard physical work, and $20 \%(n=4)$ explained that they had to go back school thus they could no longer work in vineyards. Moreover, $5 \%$ of respondents $(n=1)$ reported a visa problem as the reason for leaving the industry.

When asked how they found the job, 25 respondents $(63 \%)$ reported that they found the work by themselves, and 15 respondents $(38 \%)$ said they found their work through agents.

In order to establish the importance attached to each aspect of the problems facing the individual contractor respondents, a point allocation system was applied to the rankings of each of six factors assessed. Respondents were asked to rank from $1-6$ the most import factors to the least important factors. These were then reverse scored to give an overall indication of the most important factors as shown in Figure 1.

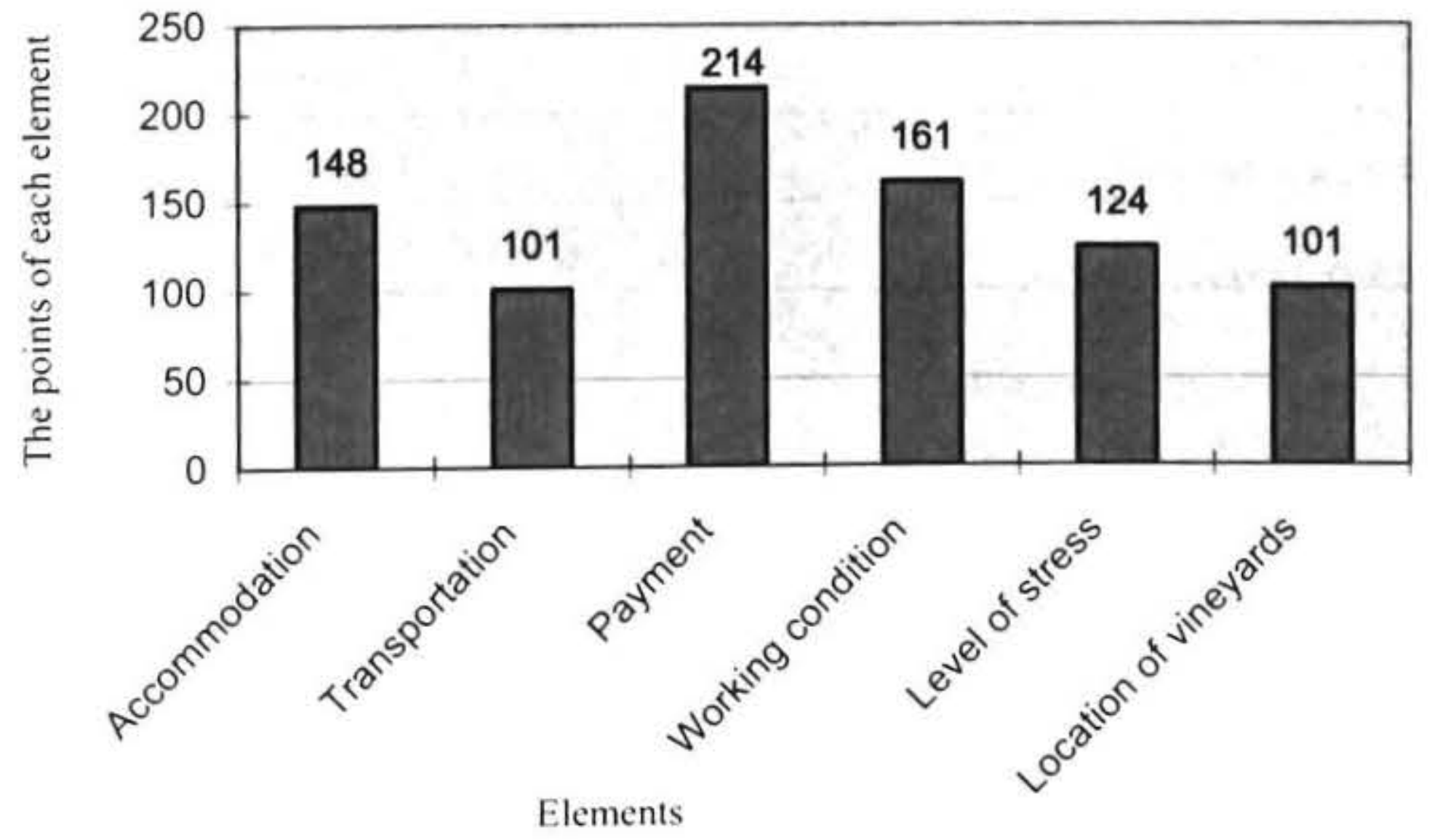

Figure 1: Ranking of the factors affecting retention in the viticulture industry 
As shown in Figure 1, wages were rated approximately $50 \%$, higher than other factors in terms of importance. Payment was followed by working conditions (161) and accommodation (148). The level of stress was reported to be slightly higher than transportation and the location of the vineyard in terms of importance.

Respondents were also asked to rank and add to a list of four factors they thought vineyard owners view as important when they are looking for contractors. Results are shown in Figure 2. Figure 2 reveals that $60 \%$ of respondents $(n=24)$ think the shortage of labour is a major concern for vineyard owners. The next most important perceived concerns were experience, personality and skills of contractors with $40 \%(n=16), 35 \%(n=14)$ and $30 \%(n=12)$ respectively. In addition, $23 \%$ of individual contractor respondents $(n=9)$ believe that vineyard owners are looking for cheaper labour. Furthermore, 10\% $(n=4), 5 \%(n=2)$ and $3 \%(n=1)$ of individual contractor respondents think vineyard owners have concerns about contractors' qualifications, visas and dependability respectively.

Finally, respondents were asked whether they would contact the vineyard owners for future work after their seasonal work was completed. 26 respondents $(65 \%)$ said they would contact the vineyard owners, and 14 respondents $(35 \%)$ said they would not.



Figure 2: Concerns of contractor's perceptions facing vineyard owners

\section{Survey Results: Perceptions Vineyard Owners and Managers}

Three of the vineyards consisted of 5.2, 6.25 and 10 hectares and one vineyard consisted of 300 hectares. Two of the four vineyard owners/managers were from the Canterbury region and two were located in the Marlborough region. They all employ casual workers for spraying, trimming, and general maintenance on an 'as needed' basis. These workers all get paid as employees. The reasons the three vineyard owners choose to employ casual workers were:

- They are managed by vineyards.

- Training is given by the vineyard owners to suit their needs.

- They are on-call so workers are available when there is work needed to be done.

The four vineyards were alike in that they all require extra workers during pruning or harvesting seasons. For these seasons they all prefer to deal with the contractorsupervisors who supply crews of workers. In general, they prefer not to recruit individual contractors because:
- They need a large number of labourers for short periods of time, such as at pruning time or for "bud rubbing" of young vines at springtime.

- They do not need to take time training these workers. The contractor-supervisors provide the associated training for their subordinates.

- They do not need to provide equipment for each individual contractor because contractor-supervisors are responsible for their own subordinates.

- They do not need to worry about workers' tax payments as the contractor-supervisors have the responsibility for this task.

- There is an agreed contract price to carry out the specified work.

In choosing to use contractor-supervisors they consider that:

- They are experienced and efficient.

- They know and understand this industry.

- They are able to carry out the tasks within the time available; have the number of people needed; and know the experience their labourers have. 
- They can supervise and train where needed.

- They are able to handle large numbers of people.

- They are available to carry out the required work at short notice for short periods of time.

The vineyard owner/managers all indicated that they would not select workers from overseas but that the contractor-supervisors may hire workers from other countries living in New Zealand. They stated that the required skills for conducting work in vineyards should be pruning skills, driving skills, selecting and picking skills, and other skills on working with facilities. They all answered that they would not directly train the subordinates of contractor-supervisors. However, they would give workers instruction or short-term supervision regarding the requirements of the work. They all agreed that individual contractors have a high rate of turnover. Reasons given for this were:

- Deinands from different vineyards.

- Workers being tourists travelling around.

- Many labourers are not available to work full time, such as university students.

- Some labourers only hold temporary working permits.

- Not enough pay forces some of them to find other work.

- Contractors supplied by the Labour department are considered unreliable.

- During long holidays or wet days, some contractors may seek other work and cannot come back immediately when the work re-starts.

\section{- Some have family problems.}

All of the vineyard owner/managers reported that they do not offer any incentives for contractors. They all keep in touch with contractor-supervisors, but not individual workers. One respondent thought that the transient nature of the contractor-supervisors was responsible for the turnover. It was indicated that if they did not return the following year, the owners would presume that the contractor-supervisor had signed up with another vineyard. The owners/managers also expressed concern regarding the contractor-supervisors reliability, and that they sometimes seek higher payments while carrying out the agreed price and work to be done. They also expressed concerns about workers' working visas and the language skills.

\section{Discussion}

Analysis of the individual contractor results of the survey revealed that $58 \%$ of those who were contractors a year before had stopped working in vineyards a year later and that $90 \%$ of workers surveyed had less than one year's work experience. This is indicative of a very high turnover rate in New Zealand. Even for industries with a significant level of low-level jobs, this is problematic and much more so for an industry that is growing as rapidly as this one is during a period of low unemployment. Opinions by Hutchinson and Wilson (2002) are that the industry will continue to face a chronic labour shortage until issues of low wages and high transport and accommodation costs are addressed. This is reflected strongly in findings of this research where $35 \%$ of individual contractor respondents reported that financial rewards have made or might make them leave the industry. This was followed by and linked to accommodation costs as $33 \%$ of respondents listed this as a major reason to leave this line of work. While some may downplay the importance of remuneration on employee turnover (Hom and Griffeth, cited in Boxall, Macky and Rasmussen 2003) it can not be overlooked as a key motivator in generally low paying occupations.

Statistics from the New Zealand wine industry reveal that the producing vineyard area has increased rapidly and that more workers are needed. This research supports this assertion as $60 \%$ of the individual contractors surveyed listed labour shortages as a major concern for vineyard owners. A major problem is the seasonal nature of the work as vineyard owners pointed out that they use contractor-supervisors to carry out work in their vineyards because they need a large number of labourers for short periods of time. This is a less than ideal solution however as the four vineyard owners/managers reported that they must take into consideration whether these contractor-supervisors have the abilities to carry out tasks within the limited time; whether they have the number of labourers needed; and what experience their workers have.

Banks, Oag and Dullahide (2004) discuss the importance of worker's skills and experience and point out that relevant experience is a major consideration for vineyard owners seeking contractors. In support, owners/managers in the study expressed that when seeking contractorsupervisors that they need to consider that: contractorsupervisors are experienced and efficient, that they know and understand the business, that they can provide the training necessary for labourers, and that they have the project management skills to carry out tasks in the time available with the skills and experience their crews of workers have. This suggests that training programs to help those intending to stay in the industry develop these essential skills are needed (Bryson and Mallon 2004).

While financial rewards and affordable housing are major factors in retaining workers, they still account for only $68 \%$ of the reported reasons for leaving the industry. It should not be ignored that there are other motivating factors that may come into play in retaining workers such as gaining meaningful work experience, opportunities to work in a natural work environment, flexible hours and opportunities to fulfil social needs. These are all considerations that affect worker turnover as they may contribute to overall job satisfaction and feeling valued (Boxall, Macky and Rasmussen 2003). Conversely, there are issues that, while of lesser concern overall, may be important to retention including: poor working 
conditions, hard physical labour and long hours as respondents listed these as factors that affect their decision to leave the industry.

Other problems to be considered in addressing the issue are the type of workers being recruited and their unique demographics as many are those who: can only work during holidays; lack adequate transportation; have families issues to consider; need visa/work permits or have language difficulties. Even though these may be lesser issues, they may still add to difficulty in recruiting and retaining the necessary number of workers needed.

\section{Limitations and Future Research}

The methodology employed included sending out 100 email questionnaires to vineyard owners throughout New Zealand. However, only two replies were received. One reason theorised is that at the time of the mailing, harvesting, which is one of the busiest times for vineyards, was underway. Therefore, it was not the 'right' time to ask vineyard owners to complete an openended questionnaire. Further research is needed to get a larger owner/management sample.

Secondly, it was not initially planned to use a telephone survey to gather input from labourers. However, during the course of the research it was found to be difficult to conduct the survey face-to-face as individual contractors were widely spread across geographic areas. Because of this, 21 of the forty questionnaires were conducted by telephone. Given that the questionnaire was not long and complicated, it was believed to be an appropriate approach. Further research could utilise more in-depth interview techniques to better understand the issues identified here.

Once into the research it was learned that there is a third party to be considered. Contractor-supervisors play a significant role between the individual contractors and the vineyard owners, particularly in large operations. Their job involves bringing crews of individual contractors to work on the vineyards. This research has not taken their views into consideration. Therefore, it is recommended that future research should include gathering information from this group. However, as an exploratory study, it is believed that even without this input, that the data collected helps understand the essential issues related to viticulture labour recruitment and retention.

Lastly, this study is limited by the location upon which data was collected as it largely represents respondents from the Canterbury and Marlborough regions. In addition, nearly $85 \%$ of the individual contractors surveyed were from China. People from other countries may have different perceptions regarding these issues. Therefore, future research should include a wider sample that reflects more viticulture regions and worker demographics.

\section{Recommendations and Conclusions}

It may not simply be an issue of addressing low wages through increased pay locally. Pay rates must be considered industry-wide because if wages are raised in one area but not another it may result in "cannibalising people from other employers" (Stuart Smith, Marlborough Wine Growers spokesman cited in Moriarty 2003). Similarly, raising wages in the industry overall will likely shift the problem to another industry (Moriarty).

Skill based pay may help retain employees and provide recognition for experience among workers thus building in more self-identification with the industry and the value of work performed (Bryson and Mallon 2004). This might be achieved through apprenticeship programs such as the one launched by the New Zealand Horticulture Industry Training Organisation ("Apprenticeships offered" 2004). Individuals who start out with little or no experience could learn skills in the essentials such as pruning, harvesting and bud-rubbing and spend non-peak times in a structured training programme that has a follow-on pathway to a tertiary based diploma or degree for learning contractor-supervisory skills.

A more aggressive stance has been taken by the Central Amalgamated Workers' Union who have employed a former PPCS union secretary to lead a series of "blitzes" on the region's vineyards to generate support for an organised work force (Wilson 2004, Mar 5). This action focused on improving the fairness of the work environment in order to retain the workers.

Another way to reduce pressure on the shortage of labour is importing labour from overseas. As reported on National News One ("Wine industry considers" 2002), the shortage of grape pruners in Marlborough has prompted contractors to try importing labourers from Tonga. Even though bringing workers into New Zealand from other countries may be a potential answer to the labour shortage, problems have occurred as workers are sometimes brought in illegally (Johnson 2004). To assist with the use of overseas labour employment, the Fruit Growers Federation has appointed co-ordinators in several parts of the country to help recruit and settle seasonal workers. Moreover, government has tried to ease the problem by fast-tracking work permit applications from foreigners in 48 hours rather than up to six weeks it takes normally (Devereux 2004).

The issue of affordable accommodation for workers is not easily addressed as the regions that are popular for viticulture have also been growing in popularity for realestate in general. Currently, Work and Income is working with the Regional Development Trust in Marlborough on options around accommodation for workers (Moriarty 2003). Employers could also look more closely at ways to provide accommodation says Moriarty such as bunk houses for seasonal workers and providing nightly meals for workers. This might also help to fulfil some of the social needs that individual contractors in this study identified as motivators for staying with a particular vineyard. Moreover, if transportation is an issue, a central pick-up point outside the central area where accommodation is at a premium could be arranged to provide transport to and from where workers need to go. 
Finally, maintaining high standards for contractorsupervisors is also needed. The problem with some businesses that pull together crews of people to work in the vineyards is that they are sometimes "fly by night" operations that offer to do the work at low prices and will put pressure on long-term contractors whose fee structure takes into account all their costs when quoting a price for a vineyard contract (Bob Lee, Marlborough Horticulture, cited in "Grape Contractors" 2004). Recommendations given by vineyard owners/managers for selecting and retaining contractors through effective relationships with contractor-supervisors in this included monitoring to ensure they treat workers fairly; make sure all agreements are clear and providing social activities and flexible contractor management.

\section{References}

Apprenticeship offered in viticulture. (2004, June 16). Marlborough Express. Retrieved June 30, 2004 from the World Wide Web: http://www.stuff. co.nz/

Banks, A. Oag, D. and Dullahide, S. (2004). Growing wine grapes before your start. Retrieved March 6, 2004 from the World Wide Web: http://www. dpi. qld. gov.au/

Benefits of bumper winegrape crop spill into economy. (2004, June 29). The New Zealand Herald. Retrieved September 27, 2004 from the World Wide Web: http://www. nzherald.co.nz/

Boxall, P. Macky, K. and Rasmussen, E. (2003) Labour turnover and retention in New Zealand: The causes and consequences of leaving and staying with employers. Asia Pacific Journal of Human Resources , 41(2). 195-214

Devereux, M. (2004 January 27). Labour shortage may force growers to recruit overseas. The New Zealand Herald. Retrieved March 6, 2004 from the World Wide Web: http://www. nzherald.co.nz/

Easton, B. (2004, May 13). Taranaki know-how on the vine. The Daily News. Retrieved July 20, 2004 from the World Wide Web: http://dnews. knowledge-basket.co.nz/

Grape contractors seek ways to counter cut-price 'cowboys'. (2004, February 20). The Marlborough Express. Retrieved July 20, 2004 from the World Wide Web:http://dnews. knowledge-basket.co.nz/

Hutchinson, D. and Wilson, S. (2002, February 2). Workers are not getting enough pay. Marlborough Express. Retrieved March 11, 2004 from the World Wide Web: http://dnews.knowledgebasket.co.nzl
Johnson, A. M. (2004 January 20). People-smugglers busted. The Dominion Post. Retrieved March 6, 2004 from the World Wide Web: http://www.stuff.co.nz/

Labour crews act as 'temps'. (2001, June 19). The Nelson Mail. Retrieved July 20, 2004 from the World Wide Web:http://dnews.knowledgebasket.co.nz

Moriarty, A. (2003, March 5). Wages must go up. The Nelson Mail. Retrieved July 20, 2004 from the World Wide Web:http://dnews.knowledgebasket.co.nz/

New Zealand Wine Online. (2004). New Zealand wine regions and statistics. Retrieved March 10, 2004 from the World Wide Web: http://www. nzwine.com/

Porter, M. (2001). Shrinking job market big worry for fruit growers. The Marlborough Express. Retrieved July 20, 2004 from the World Wide Web:http://dnews.knowledge-basket.co.nz/

Shortage of labour threatens vineyards. (2002 June 6) The Dominion. Retrieved March 11, 2004 from the World Wide Web: http://dnews.knowledgebasket.co.nz

Wilson, S. (2003, February 5). A fruitful life. Marlborough Express. Retrieved July 20, 2004 from the World Wide Web:http://dnews knowledge-basket.co.nz/

Wilson, S. (2003, March 5). Workers' union plans blitz in Marlborough vineyards. Marlborough Express. Retrieved March 11, 2004 from the World Wide Web:http://dnews.knowledge-basket.co.nz/

Wine industry considers importing labour. (2002, June 5). Marlborough Express. Retrieved March 11, 2004 from the World Wide Web:http://dnews. knowledge-basket.co.nz/ 